\title{
Economic Impact of Dissemination of Management Strategies for Sucking Insect Pests on Transgenic Cotton in Punjab, India
}

\author{
R. S. CHANDI*, V. KUMAR, A. K. DHAWAN and S. SAINI \\ Department of Entomology, Punjab Agricultural University, Ludhiana-141 004, Punjab, India
}

(Received: 9 October 2014; accepted: 12 November 2014)

\begin{abstract}
Integrated pest management (IPM) strategies for the management of sucking insect pests were disseminated in 36 villages of three districts of Punjab during 2008 to 2010. Adoption of IPM strategies led to reduction in the population of jassid, whitefly and mealybug in IPM villages. Mean population of jassid was 0.62 and 1.60 nymphs per three leaves, whitefly 1.11 and 2.53 adults per three leaves and mealybug 0.53 and 1.03 per $2.5 \mathrm{~cm}$ of central shoot in IPM and non-IPM villages, respectively. Mean population of spiders, chrysoperla, coccinellids and predatory bugs was $0.65,0.13,0.15$ and 0.04 in IPM villages and $0.29,0.09,0.06$ and 0.00 per plant in non-IPM villages, respectively. IPM strategies resulted in the 47.69 and 50.56 per cent reduction in number of spray and cost of spray in IPM villages over non-IPM villages. The average cost of cultivation was Rs. $21324 \mathrm{ha}^{-1}$ in IPM villages, as compared to non-IPM villages (Rs. $23774.67 \mathrm{ha}^{-1}$ ). Average seed cotton yield in IPM villages was $2333 \mathrm{~kg} \mathrm{ha}^{-1}$ in comparison to non-IPM villages (1959.67 kg ha-1) and average net return in IPM villages was Rs. $57194 \mathrm{ha}^{-1}$, which was Rs. 15709 more than non-IPM villages.
\end{abstract}

Keywords: IPM, non-IPM, sucking insect pests, Bt cotton, economics.

Cotton (Gossypium spp.) is a major field crop in many countries, constituting a valuable cash crop for many smallholders in developing countries. Cotton, being the most important commercial crop plays a vital role in social and monetary affairs of India. Besides other causes, major bottleneck in cotton cultivation is biotic stresses due to attack of insect pests and diseases, which play a significant role in achieving optimum yield potential. At world level 1326 species of insects harbour cotton plants (Hargreaves, 1948) and in India, 162 insect species have been reported of which nine are of utmost importance inflicting significant losses in yield (Dhaliwal et al., 2004). In Punjab, there has been a change in pest scenario in the last decades. Besides increasing cost of production and environmental problems, the excessive and indiscriminate use of insecticides for the control of these insect pests has resulted in development of insecticidal resistance, decline in natural enemies population and resurgence of the insect pests like whitefly, Bemisia tabaci (Gennadius) and jassid, Amrasca biguttula biguttula (Ishida). Besides, these, other sucking pests like thrips, Thrips tabaci Lindeman hitherto occurring during May-June and aphids, Aphis gossypii Glover at fag end of the crop season are also gaining im-

* Corresponding author; e-mail: rschandi@pau.edu 
portance. During 2006, a new sucking pest, mealybug, Phenacoccus solenopsis Tinsley appeared in few pockets of Bathinda, Ferozepur and Muktsar districts of Punjab State and caused economic loss (Dhawan et al., 2007). Mealybug, a minor pest, which was earlier supposed to be suppressed with the use of insecticides, attained the pest status. In 2007, this pest wide spread to other parts of the state and became a menace of great challenge for cotton production. Mealybug because of its high reproductive potential, wide host range, powdery/waxy surface of its body and specific feeding behaviour on the apical and lower stem portion of plant is very difficult to control with insecticides only and there is a need of integrated pest management (IPM). Looking into the potential of these insect pests to cause economic losses and sustainability of cotton production, it becomes necessary to develop and disseminate management strategies. Keeping in view the above facts, our main emphasis was to disseminate IPM technologies for the management of sucking insect pests on cotton.

\section{Materials and Methods}

Thirty-six villages were adopted for dissemination of IPM strategies for the management of sucking insect pests in three districts viz. Muktsar, Bathinda and Ferozepur in cotton belt of Punjab State during 2008, 2009 and 2010. In each of the three districts, four villages were selected for dissemination of IPM strategies during all these years. In Muktsar district villages adopted were Goniana, Chak Tamkot, Chibbran wali, Khunde Halal, Kot Bhai, Lambhi, Khanne ki Dhab, Tharajwala, Kothemannwala, Bharu, Husner and Butter. In Bathinda district villages adopted were Jangi Rana, Pakka Khurad, Kot Guru, Mehma Sawai, Baho yatri, Beer Behane, Bajoana, Kalayan Sukha, Shekhpuara, Bhgwanpura, Lalewala and Nawan Pind. In Ferozepur district villages adopted were Jadnwala Kharta, Korian Wali, Aliana, Ghattian Wali, Mamukhera, Khandwaa Hazarkhan, Thliwala Jatta, Almgarh, Dharangwala, Roorianwali, Khatwan and Cholara. Twelve villages adjoining to IPM villages were kept as check and these constituted the non-IPM villages. Bt cotton (genetically modified cotton variety which expresses Bt genes and produces Bt Cry protein) crop was grown as per recommendation of Punjab Agricultural University, Ludhiana (Anonymous, 2009). All the selected villages were regularly visited twice a week from time of sowing till harvesting to disseminate the IPM strategies and to up scale the knowledge of farmers. Awareness campaign on weed eradication, removal of stacks from fields, sowing of barrier crops and other cultural practices were carried out in these villages. Farmers trainings were conducted to aware the farmers about the recommended varieties, fertilizer application and right use of insecticides. Farmers were given knowledge about spray techniques, judicious use of pesticides and ill effects of tank mixtures of pesticides. Farmers were guided about the benefits of recommended pesticides and harmful effects of unrecommended pesticides on cotton crop. Almost 100 per cent of farmers adopted spot treatment technology and used recommended insecticides for the control of mealybug in adopted villages. At least 50 farmers from each village were selected as a target group for dissemination of IPM strategies. The IPM module of cotton implemented in selected villages is as follows: 


\section{Window I (Till 60 days after sowing)}

- Timely sowing of recommended Bt cotton cultivars resistant to bollworms and tobacco caterpillar

- Proper spacing and judicious use of fertilizers

- Eradication of weeds in or around the cotton fields to prevent multiplication of mealybug and whitefly

- Avoidance of insecticides for sucking pest in order to conserve the natural enemies, because population of these pests remains below economic threshold level in this period

- Trees and fruit plants near cotton fields harboring mealybug population should be sprayed with recommended insecticides

- Grow maize, pearl millet and sorghum as barrier crops, being least preferred hosts of mealybug

\section{Window II (61-90 days after sowing)}

- Regular surveillance and monitoring of insect pests

- Use of recommended insecticides at economic threshold level. For jassid imidacloprid@100 ml ha ${ }^{-1}$ or thiamethoxam 25WG @ $100 \mathrm{~g} \mathrm{ha}^{-1}$, for whitefly triazophos@1500 ml ha ${ }^{-1}$ or ethion@ $2000 \mathrm{ml} \mathrm{ha}^{-1}$ and for mealybug buprofezin 25EC or profenophos 50EC @ $1250 \mathrm{ml} \mathrm{ha}^{-1}$ can be used

- Do not spray against minor lepidopterans

\section{Window III (91-120 days after sowing)}

- Use of pheromone traps for monitoring of bollworm moths

- Scouting for whitefly and mealybug populations and need based application of insecticides

- Need based use of novaluron as first spray for the control of tobacco caterpillar and buprofezin for the control of mealybug as spot treatment

- Use of non-chemical methods for control of mealybug

- Avoid using synthetic pyrethroids after September 15 to minimize resurgence of whitefly

\section{Window IV (Prevention of carryover of mealybug during off-season)}

- Spray infested plants of cotton after last picking

- Dislodge the mealybug by shredding the infested sticks against ground and destroy them by burying deep in to the soil

- Remove the stacks of cotton stick from the fields and destroy the mealybug by burying them in the soil

- Do not stack the cotton sticks in the field and prevent the movement of sticks from the infested areas to the new areas 


\section{Results}

\section{Impact of IPM technology}

IPM technology was disseminated in adopted villages in which approximately 10723 ha area was covered under cotton and about 2324 farmers followed IPM strategies to control different insect pests, reduce cost of cultivation and increase yield. Also, impact of technology was seen on sowing time and variety selection and all other agronomic practices. The area under cotton hybrids recommended by Punjab Agricultural University, Ludhiana and Genetic Engineering Approval Committee, Government of India was 83.61 and 82.33 per cent during 2008 and 2009. In 2010, area under recommended varieties decreased to 74.25 per cent because of non-availability of seed of recommended varieties. But overall, 80.06 per cent area was grown with recommended varieties in Punjab. The major achievement of this study was that there was negligible area under unrecommended hybrids like Gujrat Bt in the adopted villages.

\section{Incidence of sucking insect pests}

The pest incidence in general was below economic threshold level (ETL) in IPM villages and comparatively lower than non-IPM villages. Mealybug was more in 2008 but its population decreased in coming years with the proper dissemination of technology for its management. Population of natural enemies including spiders, predatory bugs and ladybird beetle was more in adopted villages as compared to non-IPM villages during three years.

Mean jassid population was 0.62 nymphs per three leaves in IPM villages and was comparatively lower than non-IPM villages (1.60 nymphs/3 leaves). In IPM villages peak population of jassid was observed during the $31^{\text {st }}$ standard meteorological week (SMW), whereas in non-IPM villages the peak was observed during the $35^{\text {th }}$ SMW. Mean population of whitefly was 1.11 and 2.53 adults per three leaves in IPM and non-IPM villages, respectively. The peak population of whitefly in both IPM and non-IPM villages was observed in the $33^{\text {rd }} \mathrm{SMW}$ (Fig. 1). The mean population of mealybug per $2.5 \mathrm{~cm}$ of central shoot was 0.53 in IPM and 1.03 in non-IPM villages. Population of tobacco caterpillar was negligible in IPM villages due to the large scale adoption of Bollgard II cotton which provides protection against bollworms as well as tobacco caterpillar, however, in non-IPM villages its population was 0.28 larvae per plant. Population of natural enemies including spiders, chrysoperla, predatory bugs and ladybird beetles was more in IPM villages as compared to non-IPM villages. Among natural enemies, the mean population of spiders, chrysoperla, coccinellids and predatory bugs was $0.65,0.13,0.15$ and 0.04 in IPM villages and 0.29, 0.09, 0.06 and 0 per plant in non-IPM villages, respectively (Fig. 2).

Survey for mealybug was carried out in adopted villages during 2008-2010. In all the three districts overall mean number of mealybug on weeds in and around cotton fields was 0.59 weed plant (Fig. 3). In districts Ferozepur, Bathinda and Muktsar mean number of mealybug per weed plant was $0.54,1.03$ and 0.19 , respectively. Highest number (2.76) was found in district Bathinda during the $27^{\text {th }}$ SMW. On weeds grown at wastelands, 
- Jassid nym ph (IPM) $\square$ Jassid nymph (Non-IPM) 『 Whitefly adults (IPM) $\square$ Whitefly adults (Non-IPM)

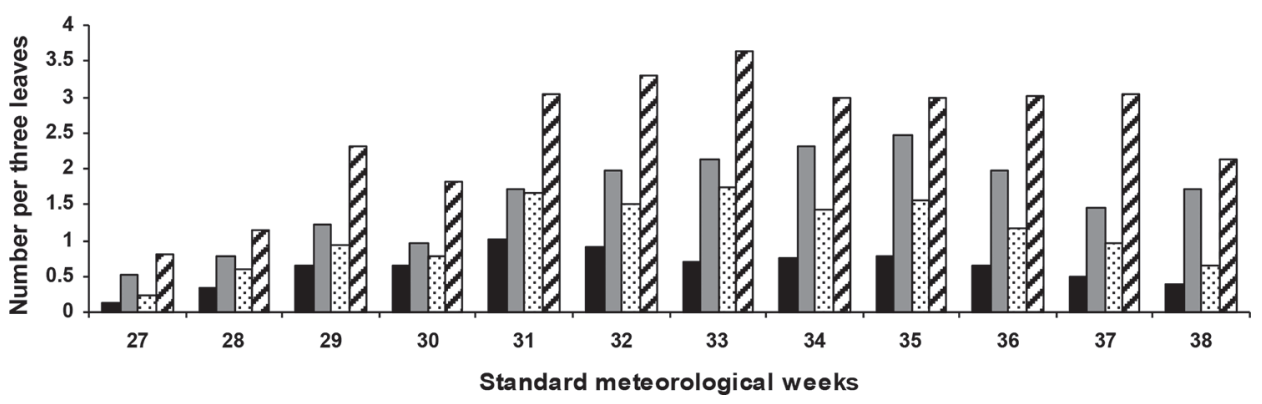

Fig. 1. Incidence of sucking insect pests in cotton during three years in Punjab

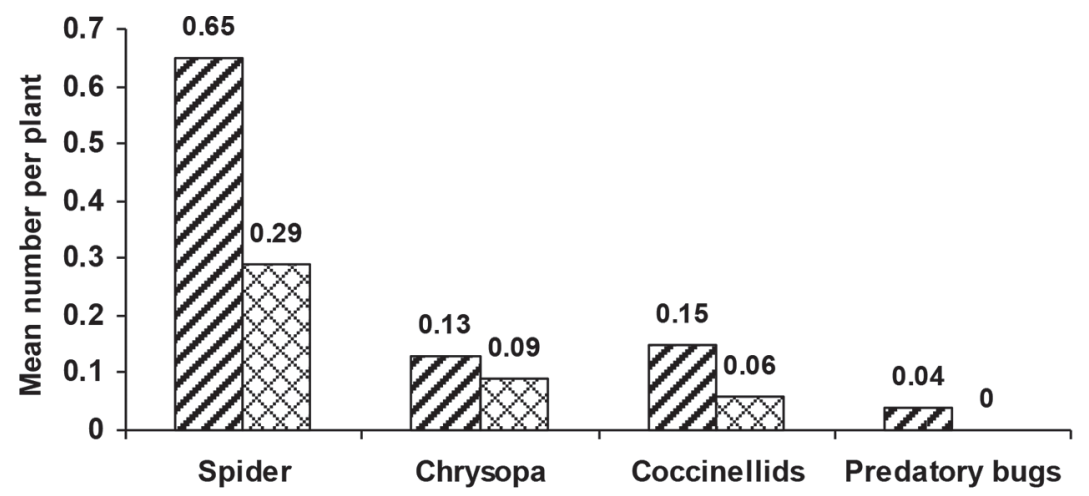

Fig. 2. Population of natural enemies in cotton during three years in Punjab

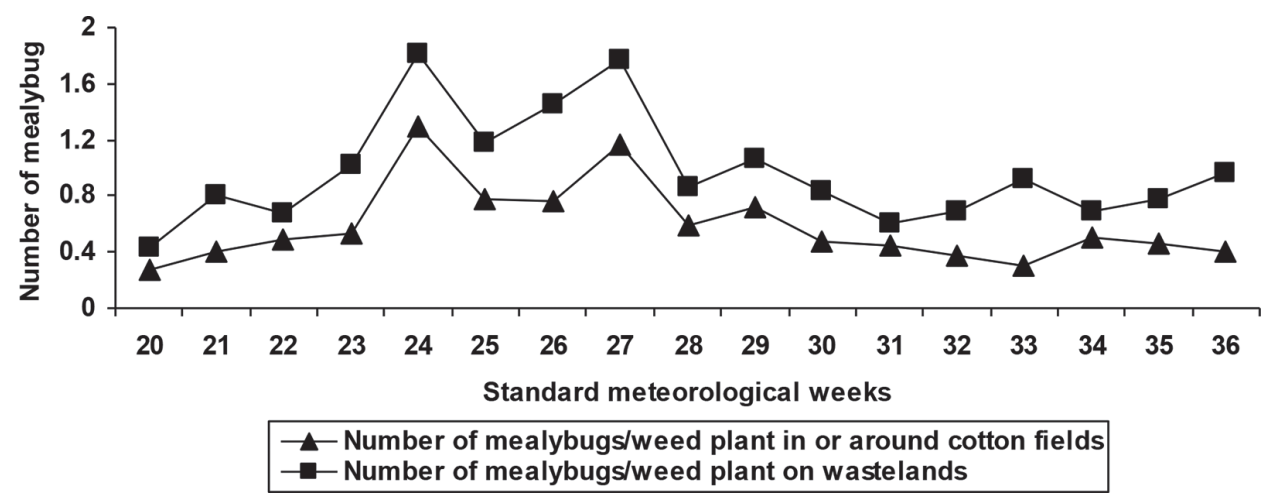

Fig. 3. Incidence of mealybug in IPM villages during three years in Punjab 
mean mealybug population was 0.97 mealybugs per weed plant. In districts Ferozepur, Bathinda and Muktsar mean number of mealybug on wastelands was 0.65, 2.10 and 0.30 per weed plant, respectively. Mealybug incidence was reported on weeds like Parthenium hysterophorus (congress grass), Trianthema portulacastrum (itsit), Xanthium strumarium (gutputna), Amaranthus viridis (chulai), Achyranthus aspera (puthkanda), Datura stramonium (datura), Sida sp. (kanghi buti) and Abutilon sp. (peeli buti).

\section{Number of sprays}

Mean number of insecticide sprays for sucking pests, foliage feeders and bollworms were high in non-IPM villages than IPM villages. In Punjab, mean number of sprays were 3.50, 3.79 and 3.36 during 2008, 2009 and 2010, respectively, in IPM villages with overall mean of 3.55 sprays in the three years, whereas, in non-IPM villages mean number of sprays was 8.83, 6.25 and 5.58 during 2008, 2009 and 2010, respectively, with overall mean of 6.89 sprays (Table 1). In 2008, the number of sprays included 0.90 sprays for the control of mealybug but in next two years due to dissemination of mealybug management strategies in adopted villages, no spray was given by the farmers. Per cent reduction in number of sprays was highest in IPM village of Muktsar (48.21\%) followed by Bathinda $(46.73 \%)$ and Ferozepur (44.77\%) over non-IPM villages. Mean per cent reduction of sprays was 47.69 in Punjab (Table 2).

\section{Spray cost}

Spray cost was also higher in non-IPM villages as compared to IPM villages (Table 2). It was highest in villages of Ferozepur i.e. Rs. 2150.67 and lowest (Rs. 1831.33) in IPM villages of Muktsar district. However, it was Rs. 4518 in villages of Ferozepur district in non-IPM villages. Overall, in three years, mean spray cost was Rs. 1972.33 in IPM villages and Rs. $4323 \mathrm{ha}^{-1}$ in non-IPM villages. Per cent reduction in spray cost was highest in Muktsar (53.49) followed by Bathinda (49.41) and Ferozepur (49.17). In IPM villages of Punjab, per cent reduction in spray cost was 50.56 over non-IPM villages.

\section{Cost of cultivation}

In three years, the cost of cultivation was higher in non-IPM villages than IPM villages (Table 1). In Bathinda, it was $21383 \mathrm{ha}^{-1}$ followed by $21330 \mathrm{ha}^{-1}$ in Muktsar and $21260 \mathrm{ha}^{-1}$ in Ferozepur in IPM villages. During three years, cost of cultivation was highest in 2010, because most of the farmers wanted to grow Bollgard II and they purchased seed at high cost, and also in this year attack of whitefly was more and farmers used costly insecticide for the control of this pest which ultimately raised the cost of cultivation (Rs. 26463 ha $^{-1}$ ). In Punjab, it was Rs. 21324 ha $^{-1}$ in IPM villages as compared to Rs. 23842 $\mathrm{ha}^{-1}$ in non-IPM villages. The per cent reduction in cost of cultivation was 11.31. 


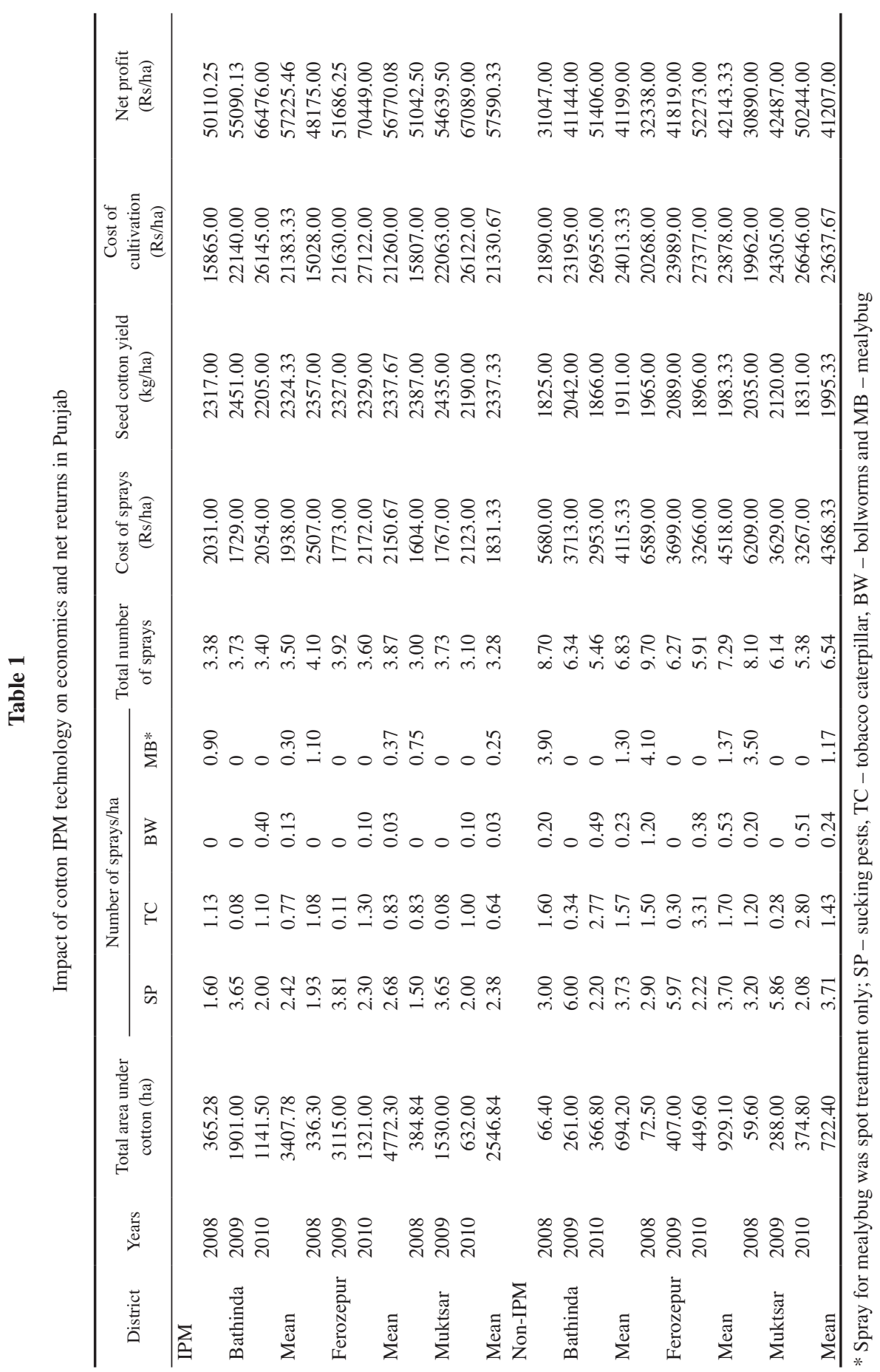




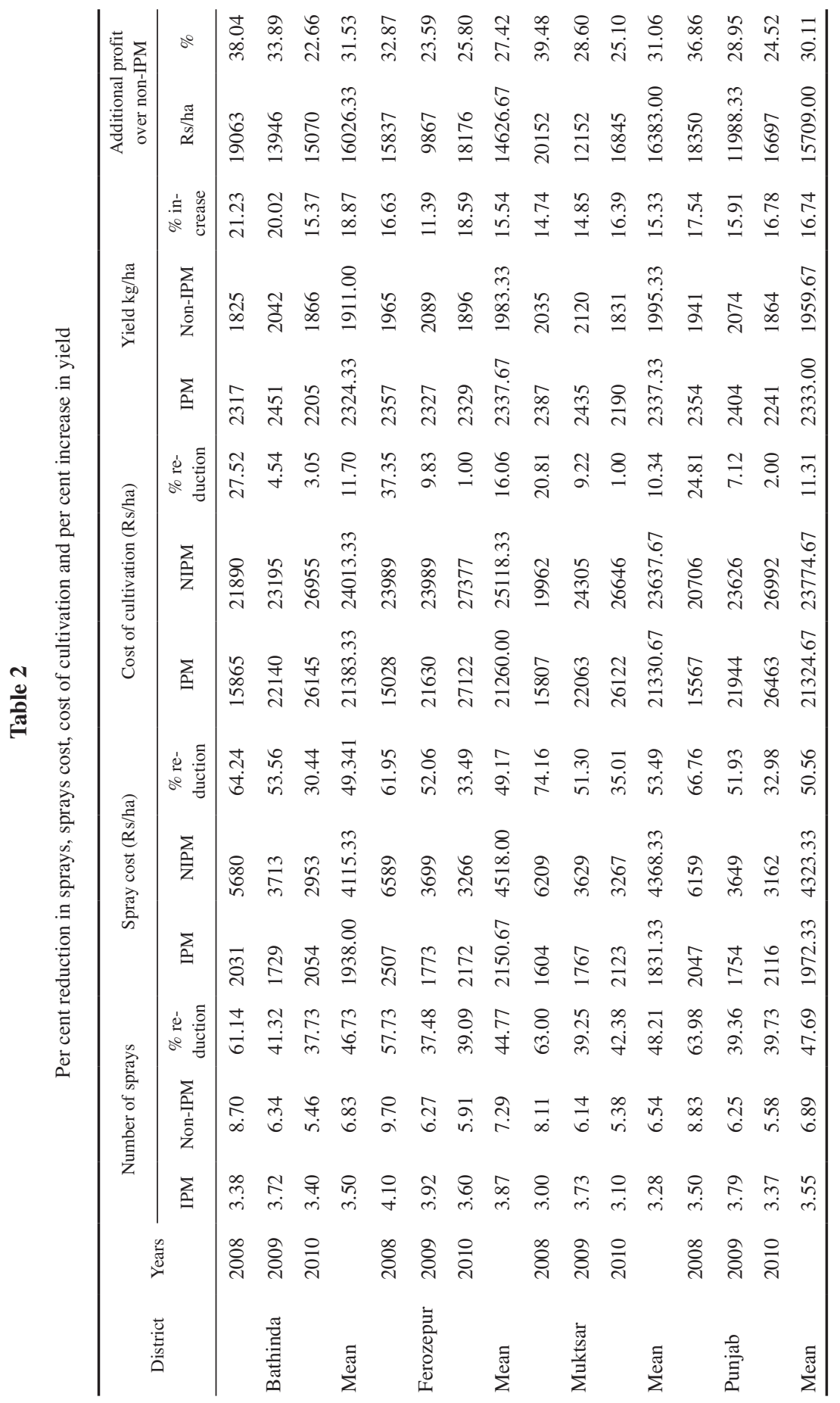

Acta Phytopathologica et Entomologica Hungarica 50, 2015 


\section{Seed cotton yield}

Seed cotton yield was higher in IPM villages than non-IPM villages (Table 2). In Punjab yield was highest in the year of 2009 (2404 kg ha-1) followed by $2354 \mathrm{~kg} \mathrm{ha}^{-1}$ in the year 2008 and was lowest in 2010 (2241 $\left.\mathrm{kg} \mathrm{ha}^{-1}\right)$. In 2010, yield was low due to dry spell in the beginning and heavy rainfall at flowering stage which ultimately reduced the yield. Per cent increase of yield in IPM villages over non-IPM villages was highest in 2008 (17.54\%) followed by 2010 (16.78\%) and 2009 (15.91\%). Overall in Punjab, yield in IPM villages was $2333 \mathrm{~kg} \mathrm{ha}^{-1}$ as compared to $1959 \mathrm{~kg} \mathrm{ha}^{-1}$ in non-IPM villages and per cent increase in seed cotton yield in these villages was 16.74 per cent in three years.

\section{Net profit}

Net profit was higher in IPM villages than non-IPM villages (Table 2). It was highest in 2010 (Rs. 68004 ha $^{-1}$ ) followed by 2009 (Rs. 53805 ha $^{-1}$ ) and 2008 (Rs. 49775 ha $^{-1}$ ). Per cent increase in net profit was highest in 2008 (36.86\%) and lowest in $2010(24.52 \%)$ over non-IPM. In Punjab, net profit was Rs. 57194 ha $^{-1}$ in IPM villages as compared to Rs. $41485 \mathrm{ha}^{-1}$ in non-IPM villages. Addition profit was Rs. $15709 \mathrm{ha}^{-1}$. The percent increase in additional profit in Punjab was 30.11.

\section{Discussion}

Over the last two decades cotton crop has witnessed a diverse array of pest problems. The problem has arisen primarily because of the increasing trend on the part of the growers to depend mainly on toxic pesticides for pest management. This has exerted a severe impact on the natural enemies' fauna of cotton ecosystem. Further, indiscriminate use of insecticides has resulted in development of resistance in insects and resurgence of new pests besides environmental pollution and public health hazards (Mehrotra, 2000; Kranthi et al., 2002). Insecticide resistance in cotton pests has emerged as a key area of concern in cotton pest management in India. The problem of resistance has rendered insecticides a less useful and reliable tool. If cotton pest management is to be effective, it is necessary to address the problem of resistance to insecticides and devise appropriate proactive management strategies to ensure that it does not continue to impair pest management in the field and management of these insect pests needs judicious use of insecticides based on economic threshold level. At the global level, there is an increasing concern about the ill effects of the increased use of toxic insecticidal chemicals (Dhaliwal and Koul, 2007). India is the largest consumer of pesticides in the South Asian countries and third largest in the world (Dhaliwal et al., 2006). Of the total pesticides used in the country, more than 60 per cent is used in agriculture sector especially cotton crop alone. The consumption of technical grade pesticides is more than $800 \mathrm{~g} \mathrm{ha}^{-1}$ in Punjab, Haryana, Delhi and Pondicherry, much higher than in the other states of the country (Agnihotri, 2000). This increased use of insecticides has resulted in increasing cost of pest management in addition to environmental pollution and public health hazards. Thus, at present there is a 
need to explore the possibility of developing new strategies so that the sole dependence on conventional insecticides can be reduced and sustainability of pest management be maintained. The adoption of an integrated pest management strategy provides a reliable answer to the question of sustainable pest management. Our study showed that with the adoption of IPM strategies, there was less incidence of sucking pests and foliage feeders, higher number of natural enemies in IPM villages as compared to non-IPM villages. There was also reduction in number of sprays, spray cost and cost of cultivation and increase in yield and ultimately the net profit. This is in accordance with results of Kranthi et al. (2000), who reported that with the adoption of IPM strategies, number of sprays for sucking pests and bollworm complex were reduced in North India with 90 per cent reduction in sprays while seed cotton yield increased up to 59 per cent and plant protection cost reduced by 25-60 per cent. Similarly, Dhawan et al. (2011) reported 38.39 per cent reduction in the number of sprays in IPM villages over non-IPM villages with an additional profit of Rs. 14056 per hectare. Surulivelu et al. (2004) also reported 63 per cent reduction in number of sprays at Coimbatore and Theni districts of Tamil Nadu with mean of 2.7 sprays in project villages as compared to 7.3 sprays in the control villages. Similar reports were also given by Rajak et al. (1997) with 30-50 per cent reduction in pesticides consumption in insecticide resistance management (IRM) adopted fields and 21-27 per cent increase in yield. Results of present investigations also conform with Dhawan et al. (2009) who reported that adoption of IRM strategies helped in reduction of cost of spray up to Rs. 1217 $\mathrm{ha}^{-1}$, cost of cultivation up to Rs. $1620 \mathrm{ha}^{-1}$ and overall additional profit of Rs. $5435 \mathrm{ha}^{-1}$ in adopted villages. Dahiya et al. (2014) reported that population of leafhopper, whitefly and thrips throughout the season was $(2.36,6.91$ and 8.13 respectively) more in non-IRM villages as compared to IRM villages $(1.87,5.95$ and 6.46 , respectively). The insecticide usage was more in non-IRM villages compared to IRM villages. However, seed cotton yield, net profit and cost benefit ratio was more in IRM villages as compared to non-IRM villages. Thus, our study showed that with proper dissemination and implementation of IPM technologies in cotton, natural enemies can be conserved, incidence of sucking insect pests can be minimized with reduction in number of sprays, cost of spray. Further dissemination of IPM technologies to other areas is needed to increase the income of farmers with additional benefit of environment conservation.

\section{Literature}

Agnihotri, N. P. (2000): Pesticide consumption in agriculture in India: An update. Pestic. Res. J. 12, 150-155. Anonymous (2009): Package of Practices for Kharif Crops. Punjab Agricultural University, Ludhiana, India.

Dahiya, K. K., Kumar, N., Chander, S., Singh, A. and Madaan, S. (2014): Impact of insecticide resistance management strategies on sucking pest of cotton in relation to weather parameters in Hisar region. J. Cotton Res. Dev. 28, 319-323.

Dhaliwal, G. S., Arora, R. and Dhawan, A. K. (2004): Crop losses due to insect-pests in Indian agriculture: An update. Indian J. Ecology 31, 1-7.

Dhaliwal, G. S., Singh, R. and Chhillar, B. S. (2006): Essentials of Agricultural Entomology. Kalyani Publishers, New Delhi, India.

Dhaliwal, G. S. and Koul, O. (2007): Biopesticides and Pest Management - Conventional and Biotechnological Approaches. Kalyani Publishers, New Delhi, India. 
Dhawan, A. K., Singh, K., Saini, S., Mohindru, B., Kaur, A., Singh, G. and Singh, S. (2007): Incidence and damage potential of mealybug, Phenacoccus solenopsis Tinsley on cotton in Punjab. Indian J. Ecology $34,166-172$.

Dhawan, A. K., Singh, K., Arora, P. K., Kumar, T., Singh, R. and Saini, S. (2009): Adoption and impact of insecticide resistance management strategy in cotton under Punjab Conditions. Environ. Sci. 27, 250-258.

Dhawan, A. K., Kumar, V., Singh, J. and Aneja, A. (2011): Impact of integrated pest management practices on insect-pest incidence, natural enemies populations and yield of seed cotton. J. Insect Sci. 24, 80-85.

Hargreaves, H. (1948): List of Recorded Cotton Insects of the World. Commonwealth Institute of Entomology, London, pp 1-50.

Kranthi, K. R., Banerjee, S. K. and Russell, D. (2000): IRM strategies for sustainable cotton pest management in India. Pestology 24, 58-67.

Kranthi, K. R., Jadhav, D. R., Wanjari, R. R., Shaher, A. S. and Russell, D. (2002): Insecticide resistance in five major insect pests of cotton in India. Crop Prot. 21, 449-460.

Mehrotra, K. N. (2000): Status of insecticide resistance in insect pests. In: G. S. Dhaliwal and B. Singh (eds): Pesticides: Their Ecological Impact in Developing Countries. Commonwealth Publishers, New Delhi, India, pp. 30-50.

Rajak, R. L., Diwaker, M. C. and Mishra, M. P. (1997): National IPM programme in India. Pestic. Inf. 23, 23-26.

Surulivelu, T., Sumathi, E., Matharajan, V. G. and Rajendran, T. P. (2004): Evaluation of success of insecticides resistance management in Tamil Nadu. In: B. M. Khadi, M. H. Vaamadevaiah, I. S. Katageri, S. S. Udikeri Chattannawar and S. B. Patil (eds): International Symposium on Strategies for Sustainable Cotton Production - A Global Version 3. Crop Protection, Dharwad, pp. 204-207. 